\title{
Legal efforts to protect home workers in North Sumatra
}

\author{
Agusmidah ${ }^{*}$, Suria Ningsih, and Erna Herlinda \\ Faculty of Law, Universitas Sumatera Utara, Medan, Indonesia
}

\begin{abstract}
Home workers without legal protection isan international phenomenon. North Sumatra Province encounters a similar problem because this province is a strategic area for investment. Its climate, land, natural resources, and the number of the labor force are several reasons which may attract investment in North Sumatra. This problem relates to the legal basis to establishlocal regulationconcerning protection to home workers. This is because the central government has not regulated this issue in the Act No. 13 of 2003 on Manpower. Therefore, this empirical juridical study will explain the legal efforts which have been done by the community to encourage the formulation of local regulation which can protect home workers. The analysis was conducted qualitatively by describing such efforts, including forming the communities of home workers so that they can be provided with training, advocation, accompaniment, and involvement in each stage of drafting the local regulation. In addition, political approaches were also performed continuously, such as voicing opinions to the Regional Representative Council (DPRD), Department of Manpower, and academics. Although these efforts have not received a positive outcome for the enactment of the local regulation, this article will give an idea that the legal issues of home workers particularly in North Sumatra still must be strived.
\end{abstract}

\section{Introduction}

ILO Convention No.177 have decribe home workers are the workers who are working from their homes or outside from the workplace of the company or corporation. A regulation to protect home workers is necessary in order to resolve unfit conditions at work. Wages and social insurance are two most basic things that should be protected. In average, home workers have low wages. In addition, they generally do not have social insurance, health insurance, occupational injuries insurance, or even an old age insurance. Other bad conditions of the home workers are including unsupervised working hours, an involvement of children in the work, and others

Home workers have a role in microeconomics because they increase productivity and economic growth for their employers, either individuals or companies (corporations). However, the assumption that home workers areconsidered as a lower-class job which does

* Correspondent Author: midahagus@gmail.com 
not need to be regulated in the legislation is not in accordance with human rights and does not also support the purpose of being a state that protects all citizens (i.e. the Preamble of the 1945 Constitution of the Republic of Indonesia).

In Indonesia, the right to work is one of the basic rights of citizens (Article 27 paragraph (2) of the 1945 Constitution): "Every citizen has the right to work and to live in human dignity". It is further convinced as a human right (Article 28D paragraph 2 of the 1945 Constitution):"Everyone has the right to work and receive fair and reasonable remuneration and treatment in a working relationship." These reasons are quite convincing for Indonesia to formulatea regulation to protect all citizens regardless of their work type so that all citizens can get a job and live properly from the job, including home workers.

It is known that home workers have not been covered under the protection of labor laws as they are categorized into non-formal or informal economic sectors. In contrast, workers in the formal sector, such as workers in industrial sectors, are protected by the labor laws. It implies that home workers arenot considered employed by the "entrepreneurs" because the relationship between the home workers and the employers is generallybased on trust or habit.

The practice of hiring home workers in North Sumatra has quite significant numbers. The example of industries who hire home workers are in the manufacture of baby walkers, rubber slippers, fish rods, plastic mats, bedcovers, pillowcases, rolled incense, paper folders, and others. Although the home workers have been working for a long period of time, they have not received any protection as workers.

Therefore, this paper tried to describe the efforts which have been done to protect home workers, especially in North Sumatra Province. The purpose was to includehome workersin the category of workers who deserve thesupervision and protection of the statebecause their work also has a contribution to the community.

\section{Problem}

The underlying problem of this paper is the lack of protection for home workers, therefore needs to be learned the efforts that can be done to build a decent work for home workers.

\section{Research Methods}

The research location was North Sumatra Province. The data were obtained through literature study including primary legal materials, which consist of legislation and secondary legal materials such as books, scientific journals, previous research reports, and local regulation draft on the protection of home workers. In addition, primary? complementarydata, which supported the secondary data was also obtained from a Focus Group Discussion (FGD). The FGD was conducted at the Faculty of Law in the University of Sumatera Utara by presenting elements of the government (Regional Department of Manpower) as the excecutive and supervision in any labor regulation, the members of the Regional Representatives Council (abbreviated as DPRD) as the legislative and executive in North Sumatera (every province), home workers unions as the base for home workers, the non-governmental organization named "Bitra Indonesia" that organize and inisiate the protecting district regulation in North Sumatera, and academics from the Law who expert in State Law and Economics Department who expert in Manageent. Interviews were also conducted for the home workers to investigate their daily working conditions.

\section{Discussions}




\subsection{Previous Research}

A research by Bitra Indonesia found that home workers initially considered this system working relationship as advantageous for them because the work was regarded as an effort to earn extra money during their free time, and they did not have to leave the house, the children, and other domestic affairs. In addition, the work did not require a certain formal education as formal workers in the company.[1]

Siahaan[2] in his study found that home workers in North Sumatra have been there for more than fifty years, but they have never been included into the population data by the Central Bureau of Statistics (BPS). Since they did not know their work status, the homeworkers filled in their work status in the population data as unemployed (follow their husbands). The mapping conducted by Siahaan recruited homeworkers as research samples from 8 (eight) regencies/cities in North Sumatra, such as Asahan, Binjai, Deli Serdang, Medan, PematangSiantar, Serdang Bedagai, TanjungBalai, and Tebing Tinggi.

The research results of Bitra Indonesia[3] revealed the condition of home workers who havevery low wages, have no social insurance, and have no work health and safety insurance. The following Table 1 shows the data of wages of several home workers in North Sumatra.

Table 1 Wages and working hours of home workers per day (2017)

\begin{tabular}{|l|l|l|}
\hline Home workers & Wages (IDR/day) & $\begin{array}{l}\text { Working } \\
\text { hours } \\
\text { (hours/day) }\end{array}$ \\
\hline Grill fish wire weaver & 10,000 & $8-9$ \\
\hline Prayer paperspacker & 10,500 & $8-9$ \\
\hline Air mineral pipettes/straws packaging & 7,000 & $8-9$ \\
\hline Rubber sandal straps cutter & 3,000 & 9 \\
\hline Baby walkerseat tailor & 16,000 & $8-9$ \\
\hline Belau packaging & 17,000 & $10-12$ \\
\hline Incense packer & 20,000 & $8-9$ \\
\hline Shrimps peeler & 9,000 & $8-9$ \\
\hline Pillowcase tailor & 17,000 & $8-9$ \\
\hline
\end{tabular}

The results of the same research also found that the biggest problem experienced by the home workers in doing their job was the low pay or wages, followed by the problems shown in Table 2.

Table 2 Problems faced by home workers

\begin{tabular}{|l|l|}
\hline Problems & $\begin{array}{l}\text { Percentages } \\
(\%)\end{array}$ \\
\hline Too low wages & 40.76 \\
\hline Inconsistent work order & 27.17 \\
\hline Unable to negotiate & 9.13 \\
\hline Poor infrastructure access & 6.24 \\
\hline Lack of skill development, education, and training & 4.90 \\
\hline Expensive cost of materials and equipment & 3.56 \\
\hline High transportation costs & 1.78 \\
\hline Others & 6.46 \\
\hline
\end{tabular}

The study results of Haspels and Matsuura with ILO-Mampu[4]obtained a fact that home workers can be characterized according to whether they work for individual entrepreneurs or companies, often through intermediaries or agents, raw materials obtained 
from employers, wage paid per unit, and have no access to the market (not selling finished goods). However, the home workers, in fact, bear much production costs including their workplaces, equipment, electrical energy, and transportation.

Poverty and informal work system are two things, which are related to each other. Furthermore, the ILO[5]states that informal works occupy a large position in developing countries although informal works are correlated with the lack of protection, low wages, no insurance in old age or pensions, and no guarantee for work continuity.

Castel and Fortes[6]state that workers engage in the informal economy tend to be in a low-wage situation. Even when judging by the history of European countries, most occupations in the informal economy sector are occupied by undocumented immigrant populations.

Recently, the efforts to provide protection for workers/laborers through the state regulation are assumed to distort the market and cause a chaos in the market. [ ${ }^{7}$ ] This opinion, however, is refuted by several previous studies' results. The ILO, for instance, finds a fact that there is no relevant link between regulation in employment through legislation that protects workers' rights and the rate of employment growth. Conversely, the important key seems to be how to create a conducive labor climate so that entrepreneurs or investors feel comfortable opening their business in Indonesia[8].

Another view, which breaks the paradox of free market and the rights of workers/laborers is stated by Uwiyono [9]. He evaluates that the policy of low wages and the weak implementation of legislation including restrictions on the fundamental rights of the workers in a free market economy becomes the factors that would hamper the free market. This is because the policy becomes an indication of social dumping which can lead to a disruption to the implementation of fair trade in the free market. As a result, this market economy model encourages autonomy innegotiating collectivelybetween the workers andthe entrepreneurs.Utz [10] in his writing states that the free-market economy emphasizes the economic balance which lies in the balance of supply and demand whereas social equilibrium lies in the balance of the power between the workers/laborers and entrepreneurs or entrepreneurs' organization. Therefore, workers need to be unionized so that the wage rates and other terms of employment can be negotiated with the entrepreneurs.

\subsection{Work protection has not touched the non-formal sector workers}

Act No. 13 of 2003 concerning Manpower (abbreviated as UUK) regulates the protection of work for the formal workingrelationship. A formal working relationship is characterized by an employment agreement between the employer and the employee. According to the Article 1 number 15 of UUK, a working relationship contains elements of work, orders, and wages.

Imam Soepomo[11] explained the scope of labor protection in three ways, namely: (a) economic protection, defined as the protection of workers in the form of sufficient income including when the workers work out of their will; (b) social protection, defined as the protection of workers in the form of occupational health insurance, freedom of association, and the protection of the right to form an organization; and (c) technical protection, defined as the protection of workers in the form of security and safety.

A weak bargaining position of workers/laborers causes the state must have a role in providing supervision and legal protection. In addition, Sinzheimer[12] asserts that the legal employment agreement is merely a 'voluntary adherence' of the workers/laborers to the conditions set unilaterally by the employers. This view, therefore, strengthens that need for the authorities (state) to minimize inequality through legislation. 


\subsection{Legal efforts to protect the home workers}

Legal efforts in order to protect the home workers can be done by describing conditions that are often encountered and may be the causes of economic exploitation of the home workers.Following are the details:

1. The home workers provide or incur costs for working equipment and facilities, such as electricity, work equipment, storage (even at their own houses), the cost of maintaining the work equipment, and others;

2. The business owners think that it is unnecessary to do the obligations of some entrepreneurs as regulated in the labor laws and legislation because there is no employment agreement.

3. The delivery of work is usually through intermediaries, often through several levels which become the intermediaries between the employers and the workers.

The protection of home workers according to the ILO standards is by establishing the basic principles and rights at work, namely:[13]

(a) the freedom of association and the effective recognition of the right to collective bargaining;

(b) the abolition of all forms of forced or compulsory labor;

(c) the effective abolition of child labor; and

(d) the elimination of discrimination in terms of employment and position.

Decent work is central to poverty alleviation efforts and is a means of achieving equitable, inclusive, and sustainable development. A decent work also involves providing opportunities for productive employment and equitable incomes, providing security in the workplace, and providing social protection for workers and their families [14].

\subsection{Efforts which have been done to protect home workers in North Sumatra}

Efforts to protect home workers in North Sumatra have been done by both local governments and non-governmental organizations. The provincial government of North Sumatra undertakes efforts to protect home workers by proposing the formulation of local regulation (Perda). The authority to establish this regulation is based on the Act No. 23 of 2014 on Local Government, and it is also supported by the companion society of home workers, such as Bitra Indonesia and Alliance of Home Workers.

There were obstacles encountered during the process of drafting the local labor regulation in the DPRDof North Sumatra Province including the legislators' doubts concerning two reasons:

a. The legal basis because there is no law that provides instructions for the provision of the local regulation to protect home workers in the Manpower Act.

b. Regarding the investment climate, regulation can hinder investment.

The Act No. 13 of 2003 on Manpower is known to be limited in the protection of workers in the formal sector (i.e. work in the employment relationship), and it does not contain any protection for informal workers. Work relationships as legal relationshipsare important facts which provide several rights and obligations for all parties. However, in the case of home workers, one party works for another party through an intermediary or agent, so there is no working relationship between the worker and the employer[15].

Efforts were also made by convincing the DPRD in a hearing discussion (abbreviated as RDP) that the government has the right to formulate aregulation to protect its people without exception. In the process, however, the existing draft regulation was agreed not only for home workersbut also for all workers;thus, the name of the local regulation was changed from the protection of the home workers to the draft of the local labor regulation. 
In addition to local governments, the protection of home workers was also done by Bitra Indonesia cooperated with Bappenas and the ILO in a program named Mampu.Bitra Indonesia made efforts by empowering the home workers who eventually form a home workers union. The benefits of this program were as an effort to improve the capacity of home workers as part of the workforce, and to provide an assistance, training about organizational knowledge, and decent work advocacy. This program has been conducted since 2014, and home workers unions has been formed in January 2015. Since 2014, at least there are 22 sectors that have been identified by Bitra Indonesia, but there are still four regions in North Sumatra, such as Deli Serdang Regency, Asahan Regency, Medan City, and Binjai. In these four regions, there are 1465 home workers participating in the home workers union.

\section{Conclusions}

Efforts made by the government and community in North Sumatra to provide protection for home workers used legal and non-legal approaches. The effort in the legal approach was making the local regulation draft, which will be a priority to be discussed in 2018 . On the other hand, the non-legal approach was done by non-governmental organizations through several activities, such as: empower and train the home workers, gather them in workers union organizations, raise their awareness about the position of home workers, and increase their self-confidence as workers.

\section{Acknowledgements}

The authors would like to thank the Ministry of Research and Technology in the Directorate General of Higher Education who has provided a grant for an Applied Product Research scheme DRPM 2017under the contract No. 56/UN5.2.3.1/PPM/KP-DRPM/2017. We would also thank the Research Institute and the Rectorate of the University of Sumatera Utara who have given much support so that the DRPM 2017 grant can be obtained.

\section{References}

1. Bitra Indonesia, Kerangka Acuan Kegiatan, Bedah UUK No. 13 Tahun 2003 "Status Hukum Pekerja Rumahan”, Medan, Desember, (2015).

2. E. Siahaan, Bahan Paparan, Melihat Pekerja Rumahan dari Sudut Pandang Ekonomi, disampaikan dalam FGD di FH USU pada 18 Juli 2017, (2017).

3. Bitra Indonesia, Bahan Paparan, Pekerja Rumahan: Potret Buram dalam Mata Rantai Industri, disampaikan dalam FGD di FH USU pada 18 Juli 2017, (2017).

4. N. Haspels dan A. Matsuura, Pekerja Rumahan di Indonesia Hasil dari Penelitian Pemetaan Pekerja Rumahan di Sumatera Utara, Jawa Barat, Jawa Tengah, Yogyakarta, Jawa Timur dan Banten, (ILO- MAMPU, Jakarta, 2015).

5. [ILO], http://www.ilo.org/global/topics/employment-promotion/informal-economy/lang-en/index.htm (retrieved at 2nd September 2017)

6. M. Castells, A. Portes, World Underneath: The Origins, Dynamics, and Effects of The Informal Economy, in Alejandro Portes (ed), The Informal Economy: Studies in Advanced and Less Developed Country, (John Hopkins University Press, Baltimore, MD, 1989). 
7. S. Deakin, The Contribution of Labor Law to Economic Development And Growth, Working Paper No. 478, (Centre for Business Research University of Cambridge, 2016)

8. ILO, Seri Rekomendasi Kebijakan: Kerja Layak dan Penanggulangan Kemiskinan di Indonesia, Dimensi Ketenagakerjaan dalam Kebijakan Makro dan Sektoral, Jakarta, (2004).

9. A. Uwiyono,Hak Mogok di Indonesia, (PPs-FH UI, Jakarta, 2001).

10. A. F. Utz, Is The Right to Strike a Human Right?, Jurnal Washington University Law, 65, (1987).

11. I. Soepomo, Pengantar Hukum Perburuhan, (Djambatan, Jakarta, 1995).

12. L. Wedderburn, Collective Bargaining or Legal Enactment: The 1999 Act and Union Recognition, Industrial Law Journal, 29, (1) (2000).

13. ILO, Naskah Konvensi Tentang Pekerjaan yang Layak bagi Pekerja Rumah Tangga, Jenewa, (2011).

14. ILO, Profil Pekerjaan Layak di Indonesia, Jakarta, (2012).

15. Agusmidah, Proceeding Seminar Ilmiah Dies USU, Hak Ekonomi Pekerja Perempuan: Pekerja Rumahan dalam Jangkauan UU Ketenagakerjaan, Medan, (2016). 